\title{
Fenoxaprop for control of yellow bristle grass in pasture and its efficacy on other $\mathrm{C}_{4}$ grasses
}

\author{
T.K. James, A. Rahman, C.A. Dowsett and M.R. Trolove \\ AgResearch, Ruakura Research Centre, Private Bag 3123, Hamilton 3240, New Zealand \\ Corresponding author: trevor.james@agresearch.co.nz
}

\begin{abstract}
The efficacy of the herbicide fenoxaprop for control of yellow bristle grass (Setaria pumila) in pasture was evaluated in two field trials. Additionally, glasshouse experiments investigated its phytotoxicity on seven annual and four perennial $\mathrm{C}_{4}$ grass species. Results of the field trials showed good control of yellow bristle grass and consequently a very high (up to $98 \%$ ) reduction in seed head production. Fenoxaprop had no measurable effect on clover yield but the removal of yellow bristle grass resulted in higher production of perennial ryegrass (Lolium perenne). Fenoxaprop killed all the annual $\mathrm{C}_{4}$ species tested, viz. yellow bristle grass, summer grass (Digitaria sanguinalis), witchgrass (Panicum capillare), smooth witchgrass (Panicum dichotomiflorum), barnyard grass (Echinochloa crus-galli), broom corn millet (Panicum miliaceum) and crowfoot grass (Eleusine indica), but was less effective on the perennial $\mathrm{C}_{4}$ grass species, viz. Indian doab (Cynodon dactylon), Kikuyu grass (Cenchrus clandestinus), Mercer grass (Paspalum distichum) and paspalum (Paspalum dilatatum).
\end{abstract}

Keywords grass weeds, yellow bristle grass, Setaria pumila, fenoxaprop, chemical weed control.

\section{INTRODUCTION}

Yellow bristle grass (Setaria pumila) and other summer growing annual grass weeds are becoming more prevalent in Waikato and Bay of Plenty dairy pastures (Tozer et al. 2011, 2012). These grasses are of lower nutrient quality when mature (Tozer et al. 2008) and after death leave gaps in the pasture allowing other weeds to colonise (Wardle et al. 1994). Yellow bristle grass has a $\mathrm{C}_{4}$ photosynthetic pathway, germinating from October to January depending on conditions, and growing over the warmer summer months when perennial ryegrass (Lolium perenne) is less competitive (James et al. 2009; Thom et al. 1998). Some of the management options proposed to control this weed include pasture renewal after one or two summer crops (James et al. 2009) and the use of molasses and salt as attractants to increase the grazing pressure on mature plants (Tozer \& Cameron 2009).

Herbicides previously evaluated for control of yellow bristle grass include ethofumesate, 2,2-DPA, MSMA and a 2,2-DPA + carbetamide mixture. The most effective of these was MSMA but as it contains the heavy metal arsenic, it is not registered for use in pastures. Of the other herbicides, 2,2-DPA was the most effective but gave less than a $75 \%$ reduction in seed head numbers with an early December application (James \& Rahman 2009). 
The herbicide fenoxaprop-P-ethyl has been shown to provide good control of several $\mathrm{C}_{4}$ annual grass weeds among forage grasses overseas. The grass species controlled include green bristle grass (Setaria viridis), summer grass (Digitaria sanguinalis) and barnyard grass (Echinochloa crus-galli), but at rates four times higher than those recommended for use in New Zealand (Peters et al. 1989). In New Zealand fenoxaprop is supplied under several proprietary trade names for control of wild oats (Avena spp.) in wheat and perennial ryegrass at the recommended rate of $52 \mathrm{~g} /$ ha (Young 2013).

This paper reports on two field trials to evaluate the efficacy and safety of fenoxaprop for control of yellow bristle grass in pasture as well as glasshouse experiments that evaluated its efficacy on other annual and perennial $\mathrm{C}_{4}$ grasses.

\section{MATERIALS AND METHODS}

\section{Field trials}

Two trials were carried out in an established perennial ryegrass/white clover (Trifolium repens) pasture infested with yellow bristle grass. The site, on a Horotiu-Punui yellow-brown loam soil, was near Paterangi, Waikato. Trial 1 was short-term and evaluated the control of yellow bristle grass from a spring application of fenoxaprop + mefepyr-diethyl safener (Puma S). Trial 2 was longer term and monitored pasture production and composition during the 12 months following treatment.

Trial 1 was a randomised block design with four replicates and individual plot sizes of $3 \mathrm{~m} \times 10 \mathrm{~m}$, while Trial 2 was a replicated block design with four replicates and plot sizes of $4.5 \mathrm{~m} \times 80 \mathrm{~m}$. For Trial 1 the herbicide treatments (Table 1) were applied with a $\mathrm{CO}_{2}$ powered backpack sprayer fitted with a $3 \mathrm{~m}$ boom and four TeeJet AIXR 11003 nozzles delivering 200 litres/ha at $160 \mathrm{kPa}$. In Trial 2, which included only the $52 \mathrm{~g} /$ ha rate of fenoxaprop, applications were made with a quad-bike-mounted $4.5 \mathrm{~m}$ boom sprayer fitted with nine TeeJet AIXR 11004 nozzles delivering 185 litres/ha at $6 \mathrm{~km} / \mathrm{h}$ and 100 $\mathrm{kPa}$. For both trials the treatments were applied on 19 December 2011, 10 days after grazing. At the time of treatment the sward was 100-150 mm tall and the yellow bristle grass had 1-5 tillers. There was $90 \%$ cloud cover, the air temperature was $18^{\circ} \mathrm{C}$ and wind of $0-2.5 \mathrm{~m} / \mathrm{s}$. Rainfall commenced about $8 \mathrm{~h}$ after treatment and $6.8 \mathrm{~mm}$ of rain was recorded over the next $12 \mathrm{~h}$. The first grazing after the application of fenoxaprop took place 50 days after treatment in accordance with the withholding period on the product label at the time.

For both trials, visual assessments of yellow bristle grass control (combining both physical damage and ground cover compared to untreated) along with observations on any pasture damage were made at 1.5, 3, 6 and 8 weeks after treatment (WAT). Additionally in Trial 1 at 8 WAT, all seed heads in the plot were counted. For Trial 2, a $2.2 \mathrm{~m} \times 1.1 \mathrm{~m}$ cage was placed in each plot to protect an area from grazing. Within a few days of grazing the cage was moved to a new location and two $2.00 \times 0.45 \mathrm{~m}$ strips within the cage mown and the fresh weight of pasture obtained. The mower height was set to match the grazed pasture. At the same time a fresh pasture sample (circa $500 \mathrm{~g}$ ) was collected, from an area between the two mown strips, for herbage dissection analysis. Pasture composition was estimated by hand-sorting the fresh pasture sample into perennial ryegrass, white clover, yellow bristle grass, other grasses, broadleaf weeds and dead matter prior to drying. Pasture dry matter was determined by taking a $200 \mathrm{~g}$ subsample from the harvested herbage of each plot that was reweighed after drying for 16 hours at $80^{\circ} \mathrm{C}$. This was used to calculate pasture dry matter production. Additionally, the total number of yellow bristle grass seed heads was counted in each caged area about 14 months after treatment.

\section{Glasshouse experiments}

Seven annual grass species, viz. yellow bristle grass, summer grass, barnyard grass, witchgrass (Panicum capillare), smooth witchgrass (Panicum dichotomiflorum), broom corn millet (Panicum miliaceum) and crowfoot grass (Eleusine indica), were grown from seed in $150 \mathrm{~mm}$ diameter pots filled with Daltons standard potting mix. Four perennial grasses, viz. Indian doab (Cynodon 
dactylon), Kikuyu grass (Cenchrus clandestinus), Mercer grass (Paspalum distichum) and paspalum (Paspalum dilatatum), were grown from stolon fragments (75-100 $\mathrm{mm}$ long) in a similar manner. Additionally, the $\mathrm{C}_{3}$ species perennial ryegrass was also grown from seed. All the perennial species were planted on 10 January 2012 and the annual species on 17 January 2012. For the annual species there were about four plants per pot and two plants for the perennials.

The herbicide treatments (Table 2) were applied to three pots of each species on 14 February 2012 with a $\mathrm{CO}_{2}$ powered, moving belt sprayer fitted with a single TeeJet $8001 \mathrm{E}$ nozzle and operated at $200 \mathrm{kPa}$ to apply 200 litres/ha. At the time of spraying the glasshouse temperature was $24^{\circ} \mathrm{C}$. Two products containing fenoxaprop (Puma S and Foxtrot (fenoxaprop + cloquintocet-mexyl safener)) were each applied at 52 and $104 \mathrm{~g}$ ai/ha to the annual grasses and to perennial ryegrass, and at 52 and $207 \mathrm{~g}$ ai/ha to the perennial grass species. The annual grasses had 1-4 tillers, while the perennial grass had about 20 tillers on stolons up to $200 \mathrm{~mm}$ long except for paspalum, which had 4-7 tillers, 75$150 \mathrm{~mm}$ long. Assessments of herbicide damage, as percent of untreated, to the plants were made at 1, 2, 3 and 7 WAT.

On 15 June 2012, a second experiment was carried out where Kikuyu grass, Indian doab and Mercer grass were treated with 52 and $414 \mathrm{~g}$ ai/ha of either product using the same methods. These plants were larger than those of the first experiment with stolons about $300 \mathrm{~mm}$ long, having been potted up on 24 April 2012 and grown in a heated glasshouse with $20-25^{\circ} \mathrm{C} /$ $12-15^{\circ} \mathrm{C}$ day/night temperatures.

All data were analysed using analysis of variance (ANOVA). Due to their large numbers, seed head counts in the untreated control were omitted from the ANOVA for Trial 1.

\section{RESULTS AND DISCUSSION Field trials}

The early phytotoxicity symptom of fenoxaprop to yellow bristle grass is chlorosis, with the leaves turning yellow and red before necrosis occurs. In Trial 1, where some of the yellow bristle grass plants were large at the time of treatment, fenoxaprop required about 8 weeks to achieve maximum effect (Table 1). By this time the high rate of fenoxaprop had achieved $93 \%$ control of yellow bristle grass and was significantly better than the $35 \mathrm{~g} / \mathrm{ha}$ rate. Visual estimates of percent ground cover of yellow bristle grass showed similar results (data not presented). However, if seed head numbers are used as the measure of control then the 35 and $52 \mathrm{~g} /$ ha rates resulted in $94 \%$ and $98 \%$ control respectively.

Trial 2 included only the $52 \mathrm{~g} /$ ha rate of fenoxaprop and this resulted in an estimated $80 \%$ reduction in the yellow bristle grass present at 3 and 6 WAT. However, by 8 WAT, treated plots had $88 \%$ less yellow bristle grass content compared to the untreated. Subsequent dry matter measurements showed that the removal of yellow bristle grass was compensated for with an increase in pasture production during autumn and the

Table 1 Percent control of yellow bristle grass assessed at intervals and number of seed heads (number/ $30 \mathrm{~m}^{2}$ ) at 8 weeks after treatment (WAT) in Trial 1 after treatments were applied on 19 December 2011.

\begin{tabular}{|c|c|c|c|c|c|c|}
\hline \multirow[b]{2}{*}{ Treatment } & \multirow{2}{*}{$\begin{array}{c}\text { Rate } \\
\text { (g ai/ha) }\end{array}$} & \multicolumn{4}{|c|}{ Percent control } & \multirow{2}{*}{$\begin{array}{l}\text { Number of } \\
\text { seed heads }\end{array}$} \\
\hline & & 1.5 WAT & 3 WAT & 6 WAT & 8 WAT & \\
\hline Untreated & - & 0 & 0 & 0 & 0 & 1733 \\
\hline Fenoxaprop & 35 & 35 & 69 & 68 & 80 & 111 \\
\hline Fenoxaprop & 52 & 38 & 88 & 83 & 93 & 35 \\
\hline $\operatorname{LSD}(\mathrm{P}=0.05)$ & & 7.5 & 9.9 & 9.5 & 5.6 & 75.2 \\
\hline
\end{tabular}


following spring (Figure 1). However, there were no significant differences in production from the treated plots for either individual cuts or over the whole year compared to untreated. Pasture composition determinations showed the reduction in yellow bristle grass was compensated with an increase in the proportion of perennial ryegrass (Figure 2). This also appeared to have the secondary effect of reduced broadleaf weeds (narrow-leaved plantain (Plantago lanceolata), creeping buttercup (Ranunculus repens), broadleaved dock (Rumex obtusiflorus) and oxeye daisy (Leucanthemum vulgare)) in autumn and winter and led to fewer other grasses in winter and spring in the treated versus untreated plots (Figure 2). Although the results of the herbage dissection showed that there was the same amount of yellow bristle grass in both treated and untreated plots

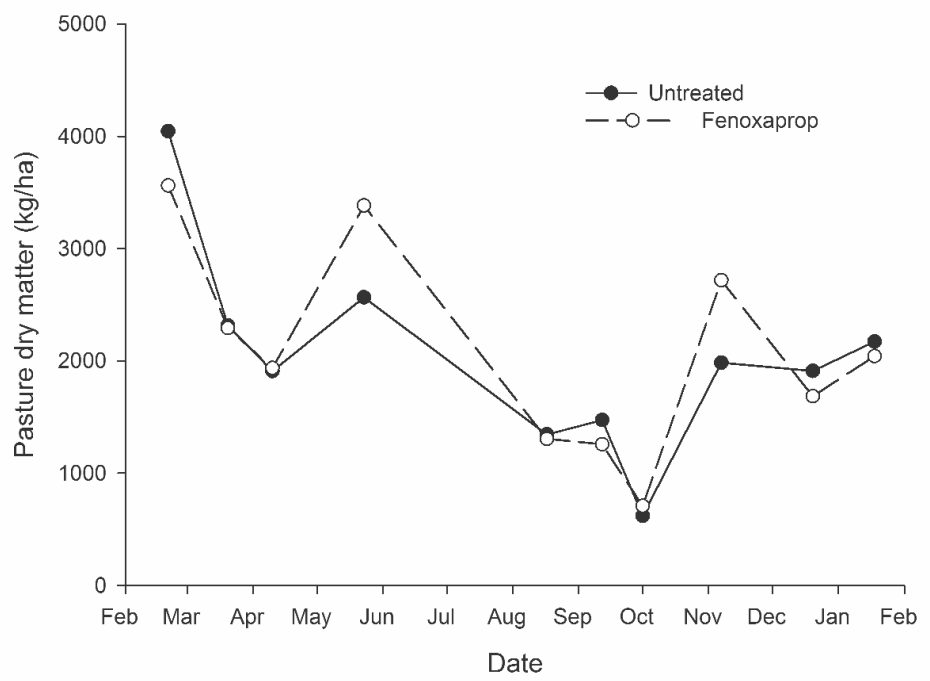

Figure 1 Mean pasture dry matter production from the untreated and fenoxaprop treated plots of Trial 2 for the year after treatment in December 2011. Differences at each harvest date were not significantly different $(\mathrm{P}=0.05)$.

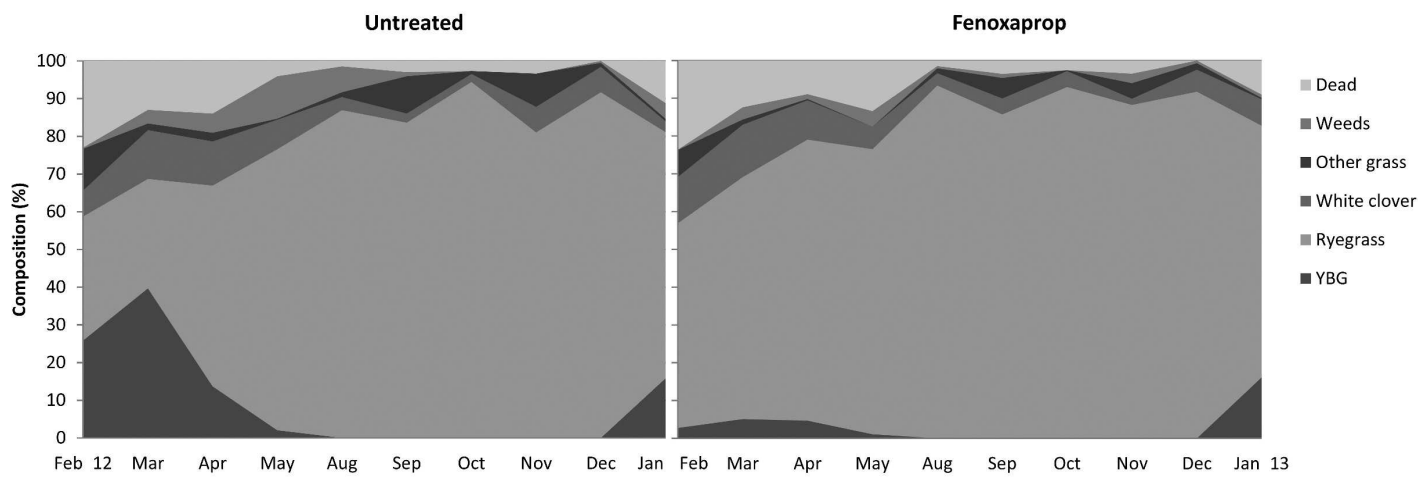

Figure 2 Percentage of total dry matter represented by various vegetation components at each harvest date for plots treated with fenoxaprop in December 2011 and untreated plots of Trial 2. 
in the summer 12 months after treatment, seed head numbers were significantly lower $(\mathrm{P}<0.05)$ in the treated plots compared to the untreated (21 and 69 seed heads $/ \mathrm{m}^{2}$ respectively).

\section{Glasshouse experiments}

The efficacy of the two products of fenoxaprop on either the annual or perennial species was not significantly different in this study, so the results were combined for analysis and for the averages in Table 2. In addition, for the annual grass species tested, the higher rate did not increase phytotoxicity. At both rates all the witchgrass and smooth witchgrass plants were dead within 2 weeks of treatment while broom corn millet, summer grass, crowfoot grass and barnyard grass required 3 weeks for a complete kill. Yellow bristle grass took the longest to control, requiring up to 6 weeks to obtain 100\% control.

Fenoxaprop showed good activity on Indian doab, Kikuyu grass and Mercer grass but was weak on paspalum (Table 2). This herbicide did not cause any damage to the young perennial ryegrass plants.

In the second glasshouse experiment on perennial $\mathrm{C}_{4}$ grass species, the plants were older and larger at the time of treatment. This resulted in reduced efficacy of fenoxaprop even though the high rate was twice that previously tested (Table 3). In this experiment, Kikuyu grass sustained more damage than either Mercer grass or Indian doab indicating that treatment in early summer when plant growth was vigorous could be a better approach, but more work is required to test this.

Data on the efficacy of fenoxaprop on potted annual grasses and perennial ryegrass in the glasshouse are probably a very good indicator of their likely effect in the field on plants of a similar age. However, the activity on the perennial plants is probably overstated as these plants did not have time to develop extensive root systems. Fenoxaprop has been evaluated for control of both

Table 2 Control ( $\%$ of untreated) of perennial, $\mathrm{C}_{4}$ grass weeds treated with fenoxaprop on 14 February 2012.

\begin{tabular}{|c|c|c|c|c|c|}
\hline \multirow[b]{2}{*}{ Herbicide } & \multirow{2}{*}{$\begin{array}{c}\text { Rate } \\
\text { (g ai/ha) }\end{array}$} & \multicolumn{4}{|c|}{ Percent control } \\
\hline & & $1 \mathrm{WAT}$ & $2 \mathrm{WAT}$ & 3 WAT & 7 WAT \\
\hline & & \multicolumn{4}{|c|}{ Mercer grass } \\
\hline Fenoxaprop & 52 & 1 & 36 & 64 & 65 \\
\hline Fenoxaprop & 207 & 4 & 60 & 89 & 89 \\
\hline \multirow[t]{2}{*}{$\operatorname{LSD}(\mathrm{P}=0.05)$} & & 3.4 & 25.8 & 7.4 & 7.4 \\
\hline & & \multicolumn{4}{|c|}{ Kikuyu grass } \\
\hline Fenoxaprop & 52 & 20 & 58 & 69 & 81 \\
\hline Fenoxaprop & 207 & 25 & 55 & 87 & 93 \\
\hline \multirow[t]{2}{*}{$\operatorname{LSD}(\mathrm{P}=0.05)$} & & 10.8 & 5.2 & 9.8 & 30.6 \\
\hline & & \multicolumn{4}{|c|}{ Indian doab } \\
\hline Fenoxaprop & 52 & 19 & 60 & 80 & 86 \\
\hline Fenoxaprop & 207 & 28 & 60 & 97 & 100 \\
\hline \multirow[t]{2}{*}{$\operatorname{LSD}(\mathrm{P}=0.05)$} & & 7.0 & - & 15.9 & 31.5 \\
\hline & & \multicolumn{4}{|c|}{ Paspalum } \\
\hline Fenoxaprop & 52 & 0 & 13 & 15 & 0 \\
\hline Fenoxaprop & 207 & 0 & 20 & 52 & 0 \\
\hline $\operatorname{LSD}(\mathrm{P}=0.05)$ & & - & 6.4 & 7.6 & - \\
\hline
\end{tabular}


Table 3 Control (\% of untreated) of perennial, $\mathrm{C}_{4}$ grass weeds treated with fenoxaprop on 16 June 2012.

\begin{tabular}{|c|c|c|c|c|c|c|c|}
\hline \multirow[b]{3}{*}{ Herbicide } & \multirow{3}{*}{$\begin{array}{l}\text { Rate } \\
\text { (g/ha) }\end{array}$} & \multicolumn{6}{|c|}{ Percent control } \\
\hline & & \multicolumn{2}{|c|}{ Mercer grass } & \multicolumn{2}{|c|}{ Kikuyu grass } & \multicolumn{2}{|c|}{ Indian doab } \\
\hline & & 3 WAT & 5 WAT & 3 WAT & 5 WAT & $3 \mathrm{WAT}$ & 5 WAT \\
\hline Fenoxaprop & 52 & 30 & 32 & 49 & 74 & 25 & 37 \\
\hline Fenoxaprop & 414 & 34 & 40 & 63 & 91 & 30 & 42 \\
\hline $\operatorname{LSD}(\mathrm{P}=0.05)$ & & 7.0 & 3.3 & 15.5 & 5.8 & 8.1 & 8.8 \\
\hline
\end{tabular}

Indian doab and Kikuyu grass in fine turf (Cudney et al. 1997). In those trials a single application of $0.42 \mathrm{~kg} /$ ha provided only $20-30 \%$ control, but seven to eight sequential applications at 4-6-week intervals over 2 years resulted in $92-96 \%$ control.

Results from the work presented here show that fenoxaprop has the potential to selectively control yellow bristle grass in pasture. Additionally, data from the glasshouse experiments, where yellow bristle grass took the longest of the $\mathrm{C}_{4}$ annual grasses to die, show that fenoxaprop should also control other annual $\mathrm{C}_{4}$ grass weeds in the sward. However, control of perennial $\mathrm{C}_{4}$ grass species will require more than a single application and is probably only cost effective in high value areas such as in fine turf.

\section{ACKNOWLEDGEMENTS}

This research was funded by Bayer (NZ) Ltd and Zelam Ltd. Thanks to Royden Hooker for providing the field trial sites.

\section{REFERENCES}

Cudney DW, Elmore C, Gibeault VA, Reints JS 1997. Common Bermudagrass (Cynodon dactylon) management in cool-season turf grass. Weed Technology 11: 478-483.

James TK, Rahman A 2009. Selective control of yellow bristle grass (Setaria pumila) in pasture. New Zealand Plant Protection 62: 217-221.

James TK, Tozer KN, Rahman A 2009. Yellow bristle grass; a recent weed incursion in Waikato dairy pastures. Proceedings of the New Zealand Grassland Association 71: 39-42.

Peters TJ, Moomaw RS, Martin AR 1989. Herbicides for postemergence control of annual grass weeds in seedling forage grasses. Weed Science 37: 375-379.
Thom ER, Waugh CD, McCabe RJ 1998. Growth and persistence of perennial and hybrid ryegrasses when grazed by dairy cows in the central Waikato region of New Zealand. New Zealand Journal of Agricultural Research 41: 477-486.

Tozer KN, Cameron CA 2009. Sweet success: managing yellow bristle grass (Setaria pumila) with grazing attractants in dairy pastures. Proceedings of the New Zealand Grassland Association 71: 43-47.

Tozer KN, Cameron CA, James TK 2012. Changes in yellow bristle grass (Setaria pumila) incidence in Waikato dairy pastures over 4 years. New Zealand Plant Protection 65:5458.

Tozer KN, Cameron CA, Thom ER 2011. Weed ingress and pasture persistence in Bay of Plenty dairy farms: field observations and farmer perceptions. New Zealand Plant Protection 64: 68-74.

Tozer KN, James TK, Cameron CA 2008. Botanical and management factors associated with Setaria pumila abundance: implications for pasture management. New Zealand Plant Protection 61: 121-126.

Wardle DA, Barker GM, Nicholson KS, Addison PJ 1994. Cyclic oscillations between summerannual $\left(\mathrm{C}_{4}\right)$ and winter-annual grass weeds in Waikato dairy pastures. Proceedings of the $47^{\text {th }}$ New Zealand Plant Protection Conference: $34-37$.

Young S 2013. New Zealand Novachem Agrichemical Manual. Agrimedia Ltd, Christchurch. 768 p. 